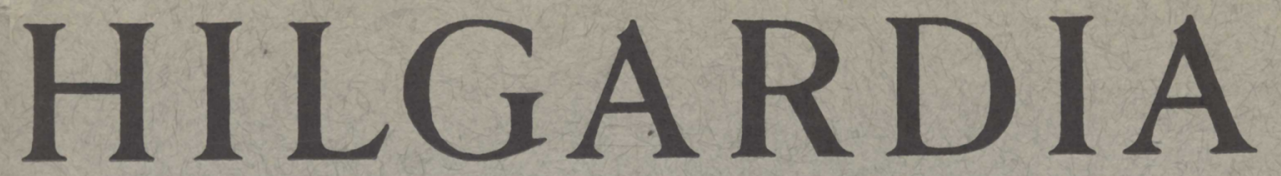

A Journal of Agricultural Science Published by the California Agricultural Experiment Station

\title{
TOXICITY OF 2,4-D IN CALIFORNIA SOILS
}

\author{
A. S. CRAFTS
}

\section{TOXICITY OF AMMONIUM DINITRO-0-SEC-BUTYL PHENOLATE IN CALIFORNIA SOILS}

\author{
A. S. CRAFTS
}




\section{SUMMARY OF CONTENTS}

\section{Toxicity of 2,4-D in California Soils}

(pages 141 to 158 )

Tests on several agriculturally important soils show that under California conditions 2,4-D retained in the soil after spraying may injure subsequent crops unless special measures are taken to supplement natural leaching and decomposition. Once decomposition occurs, crop growth is noticeably stimulated. Spraying gives more satisfactory selective control of weeds than direct application of 2,4-D to the soil. Current studies show the chemical to be practical for brush control and range improvement. Its use as a permanent soil sterilant is not recommended.

\section{Toxicity of Ammonium Dinitro-o-sec-Butyl Phenolate in California Soils}

(pages 159 to 169)

When used as selective or general contact sprays, dinitro-o-sec-butyl phenol compounds decompose too rapidly to create any problem of residual toxicity. Decomposition of dinitro selectives, like many other herbicides, causes considerable stimulation of crop growth. High cost prevents the use of these compounds for soil sterilization. In pre-emergence sprays water-soluble compounds of dinitro-o-sec-butyl phenol are not safe for tender crops, but preliminary tests indicate parent substituted phenols may be used.

In order that the information in our publications may be more intelligible it is sometimes necessary to use trade names of products or equipment rather than complicated descriptive or chemical identifications. In so doing it is unavoidable in some cases that similar products which are on the market under other trade names may not be cited. No endorsement of named products is intended nor is criticism implied of similar products which are not mentioned. 


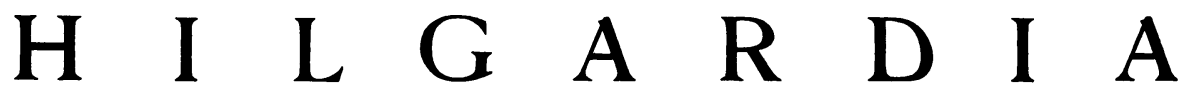

A Journal of Agricultural Science Published by

the California Agricultural Experiment Station

VOL. 19

APRIL, 1949

No. 5

\section{TOXICITY OF 2,4-D IN CALIFORNIA SOILS}

\section{A. S. CRAFTS \\ Professor of Botany and Botanist in the Experiment Station}

Studies with 2,4-D in soils have shown that, like other herbicides, it is toxic to plants when absorbed through the roots. Because of a wide variation in plant tolerance, chemicals of this type may be used selectively to kill weeds without appreciably damaging crops. And, because of their extreme toxicity, such differential action can be obtained using less than one pound of chemical per acre.

\section{SUMMARY OF PREVIOUS RESEARCH}

The work of Slade, Templeman, and Sexton $(1945)^{2}$ in England proved conclusively that 2,4-D and many other compounds having similar properties will kill weeds when applied directly to the soil. Leaching tests by Nutman, Thornton, and Quastel (1945) proved that 2,4-D was not completely removed from a Rothemsted soil by 5.6 inches of water.

In contrast to the British work, studies in this country have stressed the use of 2,4-D compounds as sprays against perennial weeds, and during the early period of investigation effects through the soil were overlooked or neglected. Many of the original containers which were used to distribute 2,4-D to users were labeled "Will not sterilize the soil." The fallacy of such labeling has been pointed out (Crafts, 1945).

Studies by De Rose at Camp Detrick (1946) confirmed the toxicity of 2,4-D in soils and showed that it could be removed by leaching. Hanks (1946) observed that leaching removed 2,4-D from limed as well as unlimed soils. An alkaline soil retained the toxicant longer than neutral or acid soils.

Taylor (1947) found 2,4-D to persist in the field seven weeks or more following treatment at four pounds per acre. Pretreatment with 2,4-D to control weeds resulted in stimulation of growth of beans and corn to values above those of control cultures. Kries (1947) found 2,4-D to persist for 18 weeks in dry soil but to decompose during four weeks of cropping in the greenhouse.

\footnotetext{
${ }^{1}$ Received for publication December 2, 1947.

'See "Literature Cited" for complete data on citations referred to in text by name of author and date of publication.
} 
Lime delayed decomposition. Some stimulation was noted where 2,4-D had decomposed. Different plants showed varying sensitivity to $2,4-\mathrm{D}$ toxicity.

Weaver (1947) studied the adsorption of 2,4-D by cation and anion exchangers. Cation exchangers in the hydrogen cycle adsorbed much 2,4-D and its salts. In the sodium- or calcium-saturated condition they adsorbed little or no 2,4-D. Anion exchangers adsorbed much 2,4-D and its salts, but not always in equal amounts. Adsorbed 2,4-D was less available to plants than that in true solution.

\section{PURPOSE OF PRESENT STUDIES}

Studies on 2,4-D in soils in California were initiated to determine :

1. The residual effects of $2,4-\mathrm{D}$ in soils

2. The possible use of $2,4-\mathrm{D}$ as a selective temporary soil sterilant under the semiarid conditions prevailing in California

3 . The possible use of $2,4-\mathrm{D}$ as a soil sterilant in nontilled areas.

Work on 2,4-D toxicity in soils began in April, 1945, and one short publication (Crafts, 1946) has presented some of the early results. The present studies involve toxicity tests in eight soils, percolation tests in five soils, and leaching tests in three soils, all soils from series agriculturally important to California. While these studies in the greenhouse were in progress, field trials (Harvey and Crafts, 1945) and many commercial applications of 2,4-D were under observation.

\section{MATERIALS AND METHODS}

The soils used in the greenhouse were stocks of air-dry surface samples that had been collected in the field and assembled in Davis several years ago. They had been pulverized and screened at the time of collection.

The toxicity tests were conducted by a method described in several previous papers (Crafts, 1935, 1936, 1945). Several series of pot cultures, each series containing 10 cultures, were grown in the greenhouse in No. 2 cans. Three test plants were used: Kanota oats, sunflowers, and Alaska field peas. The series of oat cultures contained the following concentrations of 2,4-D : $0.0,0.1,0.2,0.4,0.8,1.6,3.2,6.4,12.8$, and 25.6 p.p.m. in the air-dry soil. The sunflower and pea cultures contained 2,4-D at one tenth the above concentrations. The crops were grown 30 days from planting and then cut off at ground level and the heights and fresh weights measured.

The soils used were Aiken clay loam, Egbert loam, Hanford fine sandy loam, Sierra fine sandy loam, Stockton adobe clay, Yolo fine sandy loam, Yolo clay loam, and Yolo adobe clay. Each culture contained 500 grams of soil.

In setting up the experiments the necessary amount of 2,4-D was measured from a stock solution, diluted to a total volume sufficient to bring the soil of the culture to field capacity, and added to the soil. The cans were not perforated and all watering (tap water) was done by weight so that nothing was lost from the cans. When the first crop had been harvested the tops of the plants were returned to each culture. After drying for about 30 days the tops were removed, the soil taken out and pulverized, the tops placed in the empty can, and the soil poured in. Finally, the cultures were watered to weight and seeded. This process was repeated for each crop. 
Percolation tests were conducted using celluloid soil tubes filled with airdry soil and moistened from above through small glass pipettes adjusted to deliver about 12 drops of 2,4-D stock solution per minute. When a complete set of tubes had been moistened, each tube was laid on its side on a table and opened. The soil column was cut into eleven equal portions ; each portion was mixed, placed in a No. 2 can, and seeded. The test plants used were oats and peas, and the concentrations are given in the tables containing the crop data. These tests were designed to study retention of 2,4-D by soils.

Leaching tests were run by moistening soil tubes as explained above and then leaching each with a predetermined volume of distilled water. The leached columns were divided and seeded and the crop yield after 30 days used to measure 2,4-D toxicity in the soils.

\section{TABLe 1}

WEIGHTS (IN GRAMS) OF KANOTA OAT PLANTS GROWN IN CULTURES OF EIGHT CALIFORNIA SOILS AT VARIOUS CONCENTRATIONS OF 2,4-D

(All values are averages of two replicates)

\begin{tabular}{|c|c|c|c|c|c|c|c|c|c|c|}
\hline \multirow{2}{*}{ Soils } & \multicolumn{10}{|c|}{ 2,4-D concentrations in p.p.m. } \\
\hline & 0.0 & 0.1 & 0.2 & 0.4 & 0.8 & 1.6 & 3.2 & 6.4 & 12.8 & 25.6 \\
\hline & \multicolumn{10}{|c|}{ Kanota oats, first run, May 4-June 4, 1945} \\
\hline Aiken clay loam. & 3.9 & 3.3 & 3.5 & 3.4 & 3.5 & 2.9 & 2.2 & 1.8 & 0.9 & 0.6 \\
\hline Egbert loam............ & 7.5 & 7.9 & 7.0 & 6.9 & 7.0 & 7.4 & 6.5 & 5.0 & 2.7 & 1.4 \\
\hline Hanford fine sandy loam. & 6.9 & 7.0 & 6.7 & 6.3 & 6.5 & 5.5 & 4.2 & 1.9 & 1.0 & 0.5 \\
\hline Sierra fine sandy loam... & 3.4 & 3.1 & 2.9 & 3.0 & 3.2 & 3.4 & 3.1 & 2.7 & 2.3 & 1.9 \\
\hline Stockton adobe clay..... & 2.8 & 3.1 & 3.0 & 2.8 & 3.1 & 2.4 & 2.0 & 1.6 & 0.9 & 0.7 \\
\hline Yolo fine sandy loam.... & 5.3 & $\mathbf{5 . 1}$ & 5.0 & 5.1 & 4.7 & 2.8 & 1.6 & 0.7 & 0.4 & 0.3 \\
\hline Yolo clay loam.......... & 10.7 & 12.1 & 12.3 & 11.6 & 11.3 & 11.8 & 11.7 & 9.2 & 3.3 & 0.6 \\
\hline \multirow[t]{2}{*}{ Yolo adobe clay ........... } & 7.8 & 7.9 & 6.9 & 6.8 & 6.4 & 5.9 & 4.4 & 2.3 & 0.7 & 0.4 \\
\hline & \multicolumn{10}{|c|}{ Kanota oats, second run, July 7-Aug. 7, 1945} \\
\hline Aiken clay loam.......... & 3.2 & 3.2 & 2.5 & 3.2 & 2.9 & 3.1 & 3.2 & 3.3 & 2.4 & 2.9 \\
\hline Egbert loam........... & 7.8 & 8.1 & 7.5 & 7.5 & 7.9 & 7.7 & 8.1 & 7.6 & 8.2 & 8.3 \\
\hline Hanford fine sandy loam. & 4.6 & 4.7 & 4.0 & 3.8 & 4.0 & 3.3 & 4.3 & 4.0 & 3.4 & 3.9 \\
\hline Sierra fine sandy loam... & 4.1 & 4.1 & 3.3 & 3.7 & 3.7 & 3.4 & 3.5 & 3.7 & 4.2 & 3.8 \\
\hline Stockton adobe clay.... & 6.3 & 5.6 & 5.8 & 6.0 & 6.0 & 6.3 & 6.6 & 6.5 & 6.7 & 7.2 \\
\hline Yolo fine sandy loam.... & 2.5 & 2.6 & 2.6 & 2.8 & 2.8 & 3.7 & 3.7 & 3.8 & 1.5 & 0.6 \\
\hline Yolo clay loam.......... & 6.4 & 7.1 & 8.1 & 7.9 & 7.4 & 7.9 & 8.4 & 8.7 & 8.6 & 3.8 \\
\hline \multirow[t]{2}{*}{ Yolo adobe clay......... } & 4.3 & 4.6 & 4.6 & 4.7 & 5.2 & 5.4 & 6.2 & 7.1 & 6.3 & 1.1 \\
\hline & \multicolumn{10}{|c|}{ Kanota oats, third run, Oct. 5-Nov. 5, 1945} \\
\hline Aiken clay loam......... & 3.7 & 3.3 & 2.6 & 3.1 & 2.8 & 3.4 & 3.1 & 4.2 & 3.8 & 3.8 \\
\hline Egbert loam............ & 6.3 & 7.2 & 5.7 & 5.7 & 5.9 & 5.9 & 6.3 & 6.1 & 6.8 & 6.9 \\
\hline Hanford fine sandy loam. & 5.9 & 5.2 & 5.7 & 6.0 & 5.6 & 5.7 & 5.7 & 6.0 & 6.2 & 6.3 \\
\hline Sierra fine sandy loam... & 3.4 & 3.5 & 3.2 & 3.3 & 3.3 & 3.1 & 3.6 & 3.6 & 3.7 & 4.4 \\
\hline Stockton adobe clay..... & 3.5 & 3.6 & 4.1 & 4.1 & 3.7 & 4.2 & 3.5 & 3.9 & 4.8 & 4.7 \\
\hline Yolo fine sandy loam.... & 1.5 & 2.1 & 1.6 & 1.9 & 2.3 & 2.5 & 2.8 & 3.2 & 3.1 & 3.3 \\
\hline Yolo clay loam......... & 4.5 & 5.2 & 5.5 & 5.7 & 5.2 & 6.0 & 5.2 & 6.8 & 8.4 & 10.2 \\
\hline Yolo adobe clay......... & 3.2 & 3.0 & 3.2 & 3.0 & 3.5 & 3.8 & 4.5 & 4.5 & 6.1 & 7.5 \\
\hline
\end{tabular}




\section{RESULTS}

Toxicity. Tables 1, 2, 3, and 4 report the crop yields on the toxicity tests and figures 1 to 8 illustrate the first run data. Each series was duplicated and the values given are the averages of the two replicates. Three runs were made using oats; a final run on the same cultures was made using peas (table 4). In addition, high concentration cultures were added at the end of the first run to the series in Egbert loam and Stockton adobe clay. The results on these are included in table 4.

A study of the graphs shows that 2,4-D toxicity was high and approximately the same in Hanford fine sandy loam, Yolo fine sandy loam, and Yolo adobe clay. Next in line was Yolo clay loam, with somewhat lower toxicity, followed by Sierra fine sandy loam, Aiken clay loam, Egbert loam, and finally, Stockton

TABLE 2

WEIGHTS (IN GRAMS) OF SUNFLOWERS GROWN IN CULTURES OF EIGHT CALIFORNIA SOILS AT VARIOUS CONCENTRATIONS OF 2,4-D

(All values are averages of two replicates)

\begin{tabular}{|c|c|c|c|c|c|c|c|c|c|c|}
\hline \multirow{2}{*}{ Soils } & \multicolumn{10}{|c|}{ 2,4-D concentrations in p.p.m. } \\
\hline & 0.00 & 0.01 & 0.02 & 0.04 & 0.08 & 0.16 & 0.32 & 0.64 & 1.28 & 2.56 \\
\hline & \multicolumn{10}{|c|}{ Sunflowers, first run, May 4-June 4, 1945} \\
\hline Aiken clay loam. & 9.5 & 9.3 & 10.2 & 10.3 & 9.8 & 9.9 & 8.6 & 7.6 & 6.5 & 5.6 \\
\hline Egbert loam............ & 16.8 & 16.3 & 15.8 & 17.2 & 18.5 & 16.7 & 15.3 & 18.0 & 14.3 & 14.1 \\
\hline Hanford fine sandy loam. & 12.0 & 13.0 & 14.1 & 13.1 & 15.0 & 13.3 & 10.8 & 7.0 & 2.6 & 1.5 \\
\hline Sierra fine sandy loam... & 8.1 & 7.3 & 7.9 & 8.2 & 7.6 & 7.6 & 7.3 & 8.4 & 6.5 & 6.3 \\
\hline Stockton adobe clay.... & 10.2 & 11.0 & 10.4 & 12.1 & 11.5 & 11.5 & 9.4 & 8.7 & 9.7 & 7.3 \\
\hline Yolo fine sandy loam... & 11.6 & 11.8 & 11.9 & 11.2 & 11.2 & 10.4 & 9.2 & 5.3 & 0.6 & 0.0 \\
\hline Yolo clay loam.......... & 25.9 & 25.7 & 26.4 & 27.5 & 26.5 & 26.5 & 23.7 & 23.8 & 21.7 & 15.9 \\
\hline \multirow[t]{2}{*}{ Yolo adobe clay ......... } & 17.9 & 18.1 & 16.4 & 15.8 & 15.2 & 16.1 & 11.0 & 8.2 & 2.7 & 0.5 \\
\hline & \multicolumn{10}{|c|}{ Sunflowers, second run, July 7-Aug. 7, 1945} \\
\hline Aiken clay loam........ & 7.1 & 7.0 & 6.4 & 7.0 & 7.1 & 7.7 & 6.8 & 7.6 & 6.6 & 8.0 \\
\hline Egbert loam............ & 14.5 & 16.2 & 15.6 & 14.4 & 17.8 & 14.5 & 15.2 & 15.0 & 14.6 & 15.3 \\
\hline Hanford fine sandy loam. & 8.8 & 8.4 & 8.1 & 8.2 & 8.1 & 8.4 & 8.1 & 9.1 & 6.4 & 8.7 \\
\hline Sierra fine sandy loam... & 7.7 & 7.5 & 6.5 & 6.5 & 7.1 & 6.4 & 7.7 & 6.2 & 6.4 & 7.0 \\
\hline Stockton adobe clay.... & 11.5 & 11.9 & 11.6 & 13.4 & 12.0 & 12.7 & 13.6 & 14.2 & 11.1 & 12.2 \\
\hline Yolo fine sandy loam. & 6.7 & 7.0 & 7.6 & 7.4 & 7.8 & 7.1 & 7.9 & 8.3 & 8.6 & 8.6 \\
\hline Yolo clay loam.......... & 14.7 & 15.3 & 17.4 & 16.4 & 17.2 & 17.1 & 15.3 & 17.4 & 17.5 & 17.1 \\
\hline \multirow[t]{2}{*}{ Yolo adobe clay ......... } & 13.4 & 13.5 & 12.3 & 12.3 & 12.7 & 12.8 & 14.1 & 13.7 & 14.5 & 14.4 \\
\hline & \multicolumn{10}{|c|}{ Sunflowers, third run, Oct. 5-Nov. 4, 1945} \\
\hline Aiken clay loam. & 11.4 & 8.5 & 10.4 & 11.3 & 13.5 & 13.6 & 11.4 & 10.8 & 11.4 & 10.2 \\
\hline Egbert loam.............. & 18.5 & 17.9 & 16.5 & 18.1 & 18.6 & 15.2 & 17.4 & 15.6 & 14.3 & 15.0 \\
\hline Hanford fine sandy loam. & 13.0 & 12.4 & 12.7 & 12.1 & $12.9^{\circ}$ & 13.8 & 15.6 & 14.5 & 12.3 & 13.4 \\
\hline Sierra fine sandy loam... & 10.1 & 10.0 & 9.6 & 9.4 & 8.2 & 10.3 & 9.7 & 9.9 & 9.5 & 9.8 \\
\hline Stockton adobe clay..... & 11.2 & 12.6 & 10.4 & 11.3 & 12.8 & 11.1 & 11.7 & 11.7 & 10.8 & 11.4 \\
\hline Yolo fine sandy loam.... & 9.8 & 8.8 & 8.5 & 8.1 & 8.9 & 8.0 & 8.5 & 8.7 & 9.4 & 7.7 \\
\hline Yolo clay loam......... & 14.2 & 13.7 & 16.0 & 14.6 & 16.1 & 15.7 & 15.4 & 16.7 & 15.9 & 19.5 \\
\hline Yolo adobe clay ......... & 13.8 & 13.7 & 14.1 & 12.9 & 14.5 & 13.5 & 14.6 & 14.6 & 13.1 & 13.8 \\
\hline
\end{tabular}


adobe clay. There seems to be no simple relation between toxicity and soil characteristics among these eight soils. Except for the position of Yolo adobe clay in this line-up, a tendency toward correlation of toxicity with textural grade is discernible, toxicity being high in light, sandy soils and lower with decreasing particle size. The evidence given later that 2,4-D is retained by soils against the leaching action of moving water supports this view. On the other hand, Yolo adobe clay is an obvious exception to this rule, and no explanation is available. Because the Yolo soils are recent alluvial in origin, the adobe clay is probably water-separated instead of weathered to a clay state. Hence, though Yolo adobe clay is composed of very fine particles and displays adobe characteristics, it may be lower in actual colloid content than a soil like Stockton adobe clay. Yolo adobe clay showed anomalous behavior in arsenic studies also (Crafts and Rosenfels, 1939; Rosenfels and Crafts, 1939).

TABLE 3

WEIGHTS (IN GRAMS) OF ALASKA FIELD PEAS GROWN IN CULTURES OF EIGHT CALIFORNIA SOILS AT VARIOUS CONCENTRATIONS OF 2,4-D

(All values are averages of two replicates)

\begin{tabular}{|c|c|c|c|c|c|c|c|c|c|c|}
\hline \multirow{2}{*}{ Soils } & \multicolumn{10}{|c|}{ 2,4-D concentrations in p.p.m. } \\
\hline & 0.00 & 0.01 & 0.02 & 0.04 & 0.08 & 0.16 & 0.32 & 0.64 & 1.28 & 2.56 \\
\hline & \multicolumn{10}{|c|}{ Alaska field peas, first run, May 4-June 4, 1945} \\
\hline Aiken clay loam. & 6.0 & 6.2 & 5.9 & 6.7 & 6.5 & 6.4 & 6.2 & 4.9 & 3.1 & 1.1 \\
\hline Egbert loam ............ & 10.1 & 9.9 & 9.3 & 9.8 & 9.2 & 9.7 & 8.9 & 8.4 & 7.5 & 3.9 \\
\hline Hanford fine sandy loam. & 7.5 & 7.6 & 7.0 & 7.2 & 7.7 & 6.3 & 4.3 & 1.1 & 0.1 & 0.0 \\
\hline Sierra fine sandy loam... & 5.3 & 5.6 & 5.5 & 5.8 & 6.2 & 6.2 & 5.0 & 3.8 & 1.5 & 0.2 \\
\hline Stockton adobe clay..... & 7.9 & 8.5 & 7.3 & 9.4 & 8.2 & 8.1 & 7.2 & 8.6 & 7.7 & 5.8 \\
\hline Yolo fine sandy loam.... & 7.4 & 7.2 & 7.3 & 6.9 & 7.2 & 6.5 & 3.8 & 0.6 & 0.0 & 0.0 \\
\hline Yolo clay loam.......... & 13.4 & 12.3 & 10.2 & 12.3 & 13.0 & 11.9 & 10.0 & 2.2 & 1.3 & 0.0 \\
\hline \multirow[t]{2}{*}{ Yolo adobe clay......... } & 10.3 & 8.6 & 8.7 & 7.8 & 7.2 & 7.4 & 5.9 & 2.5 & 0.1 & 0.0 \\
\hline & \multicolumn{10}{|c|}{ Alaska field peas, second run, July 7-Aug. 7, 1945} \\
\hline Aiken clay loam. & 2.9 & 3.5 & 2.9 & 3.5 & 3.5 & 3.5 & 4.0 & 3.3 & 3.6 & 3.8 \\
\hline Egbert loam........... & 7.8 & 6.9 & 6.6 & 6.7 & 6.1 & 7.3 & 6.9 & 6.0 & 6.7 & 7.2 \\
\hline Hanford fine sandy loam. & 3.1 & 3.5 & 3.2 & 2.9 & 3.9 & 2.5 & 3.3 & 3.8 & 3.6 & 3.4 \\
\hline Sierra fine sandy loam... & 4.9 & 4.3 & 4.2 & 4.3 & 4.7 & 4.0 & 3.6 & 4.2 & 4.8 & 5.1 \\
\hline Stock ton adobe clay..... & 7.9 & 6.9 & 7.5 & 8.5 & 7.2 & 8.1 & 7.5 & 8.1 & 7.5 & 7.1 \\
\hline Yolo fine sandy loam.... & 3.1 & 3.1 & 4.5 & 4.0 & 5.0 & 4.1 & 4.1 & 3.9 & 4.0 & 3.8 \\
\hline Yolo clay loam......... & 4.8 & 4.9 & 4.5 & 5.0 & 5.1 & 5.1 & 5.2 & 5.2 & 4.7 & 5.4 \\
\hline \multirow[t]{2}{*}{ Yolo adobe clay......... } & 6.7 & 6.4 & 6.9 & 6.6 & 6.4 & 6.3 & 6.5 & 6.3 & 6.1 & 6.3 \\
\hline & \multicolumn{10}{|c|}{ Alaska field peas, third run, Oct. 5-Nov. 5, 1945} \\
\hline Aiken clay loam......... & 4.5 & 5.6 & 4.9 & 4.7 & 5.6 & 5.9 & 6.1 & 6.0 & 5.9 & 5.8 \\
\hline Egbert loam ............ & 9.8 & 8.7 & 7.4 & 6.7 & 8.7 & 7.7 & 7.1 & 5.7 & 4.8 & 6.5 \\
\hline Hanford fine sandy loam. & 7.2 & 7.0 & 5.7 & 5.8 & 6.2 & 5.4 & 3.2 & 6.0 & 5.0 & 9.5 \\
\hline Sierra fine sandy loam... & 6.2 & 5.5 & 6.1 & 6.2 & 7.0 & 6.3 & 6.1 & 6.2 & 6.0 & 5.9 \\
\hline Stockton adobe clay.... & 8.9 & 8.1 & 8.7 & 7.0 & 9.3 & 8.8 & 8.3 & 7.9 & 9.5 & 8.4 \\
\hline Yolo fine sandy loam.... & 3.2 & 3.6 & 3.3 & 3.2 & 3.9 & 4.0 & 3.8 & 3.8 & 3.5 & 3.4 \\
\hline Yolo clay loam.......... & 4.8 & 6.0 & 6.6 & 7.4 & 6.0 & 6.0 & 6.0 & 7.2 & 7.2 & 6.8 \\
\hline Yolo adobe clay......... & 8.2 & 5.0 & 6.7 & 5.0 & 5.7 & 8.4 & 5.6 & 6.7 & 8.1 & 6.7 \\
\hline
\end{tabular}


The additional concentrations added to the series in Egbert loam and Stockton adobe clay at the end of the first run proved that sufficiently high concentrations of 2,4-D will render even these soils sterile. However, by the third and fourth runs this additional chemical had decomposed in the soil.

\section{TABLE 4}

WEIGHTS (IN GRAMS) OF ALASKA FIELD PEAS GROWN IN CULTLRES OF EIGHT CALIFORNIA SOILS AT CONCENTRATIONS OF 2,4-D PREVIOUSLY SOWN TO OATS; ALSO HIGH CONCENTRATION RUNS ON OAT, SUNFLOWER, AND PEA PLANTS

\begin{tabular}{|c|c|c|c|c|c|c|c|c|c|c|}
\hline \multirow{2}{*}{ Soils } & \multicolumn{10}{|c|}{ 2,4-D concentrations in p.p.m. } \\
\hline & 0.0 & 0.1 & 0.2 & 0.4 & 0.8 & 1.6 & 3.2 & 6.4 & 12.8 & 25.6 \\
\hline & \multicolumn{10}{|c|}{ Peas, fourth run, Dec. 25, 1945-Jan. 25, 1946} \\
\hline Aiken clay loam. & 5.8 & 5.5 & 5.3 & 6.3 & 4.9 & 5.9 & 5.7 & 5.0 & 4.9 & 5.1 \\
\hline Egbert loam............ & 9.7 & 10.2 & 9.7 & 10.1 & 8.9 & 8.5 & 8.7 & 9.5 & 11.5 & 9.7 \\
\hline Hanford fine sandy loam. & 6.2 & 7.0 & 5.8 & 6.0 & 6.4 & 6.7 & 7.7 & 7.1 & 6.9 & 7.3 \\
\hline Sierra fine sandy loam... & 6.6 & 6.8 & 6.7 & 7.8 & 7.4 & 7.3 & 6.6 & 8.0 & 7.3 & 7.5 \\
\hline Stockton adobe clay..... & 8.9 & 10.1 & 9.1 & 10.8 & 8.5 & 10.1 & 10.7 & 10.5 & 10.0 & $\delta .5$ \\
\hline Yolo fine sandy loam.... & 6.0 & 5.8 & 5.3 & 4.5 & 4.8 & 3.9 & 5.8 & 4.9 & 6.0 & 5.5 \\
\hline Yolo clay loam......... & $\ldots$ & $\ldots$ & $\ldots$ & $\ldots$ & $\ldots$ & $\ldots$ & $\ldots$ & $\ldots$ & $\ldots$ & $\ldots$ \\
\hline Yolo adobe clay......... & 7.7 & 7.6 & 5.2 & 5.9 & 6.6 & 6.0 & 6.7 & 6.2 & 7.0 & 7.4 \\
\hline
\end{tabular}

2,4-D concentrations in p.p.m.

\begin{tabular}{|c|c|c|c|c|c|c|}
\hline & & & & & & \\
\hline & & & Sun & wers & & \\
\hline Egbert loam second run... & 0.4 & 0.2 & 14.2 & 13.1 & 6.0 & 5.6 \\
\hline Egbert loam third run $\ldots \ldots \ldots \ldots \ldots \ldots$ & 6.5 & 6.6 & 15.9 & 16.7 & 9.4 & 7.6 \\
\hline & & & & & & \\
\hline Egbert loam fourth run . . . . . . . . . . & 9.9 & 5.6 & $\cdots$ & $\ldots$ & 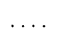 & $\ldots$ \\
\hline
\end{tabular}

2,4-D concentrations in p.p.m.

\begin{tabular}{|c|c|c|c|c|c|c|c|c|c|}
\hline & 51.2 & 102.4 & 204.8 & 5.12 & 10.24 & 20.48 & 5. 12 & 10.24 & 20.48 \\
\hline & \multicolumn{3}{|c|}{ Oats } & \multicolumn{3}{|c|}{ Sunflowers } & \multicolumn{3}{|c|}{ Peas } \\
\hline \multirow[t]{2}{*}{$\begin{array}{l}\text { Stockton adobe clay } \\
\text { second run. . . . . . } \ldots \ldots \ldots \ldots \\
\text { Stockton adobe clay } \\
\quad \text { third run } \ldots \ldots \ldots \ldots \ldots \ldots\end{array}$} & 6.8 & $\begin{array}{r}0.8 \\
7.7\end{array}$ & 0.5 & $\begin{array}{r}14.2 \\
12.9\end{array}$ & $\begin{array}{r}13.9 \\
12.9\end{array}$ & $\begin{array}{r}6.6 \\
14.4\end{array}$ & 3.2 & $\begin{array}{l}5.9 \\
4.4\end{array}$ & $\begin{array}{r}0.0 \\
7.6\end{array}$ \\
\hline & \multicolumn{3}{|c|}{ Peas } & & & & \\
\hline $\begin{array}{l}\text { Stockton adobe clay } \\
\text { fourth run ........ }\end{array}$ & 9.8 & 8.7 & 8.0 & & & & & & \\
\hline
\end{tabular}


Examination of the data for the second and third runs proved that in practically all cases the chemical had so decomposed that little toxicity was left. In all cases by the third run cultures somewhere along in the series were heavier than the untreated checks. In the heavy soils some crops were up to twice or more the weight of the checks, indicating definite stimulation. Such stimulation has been noted in a number of studies on such herbicides as borax,

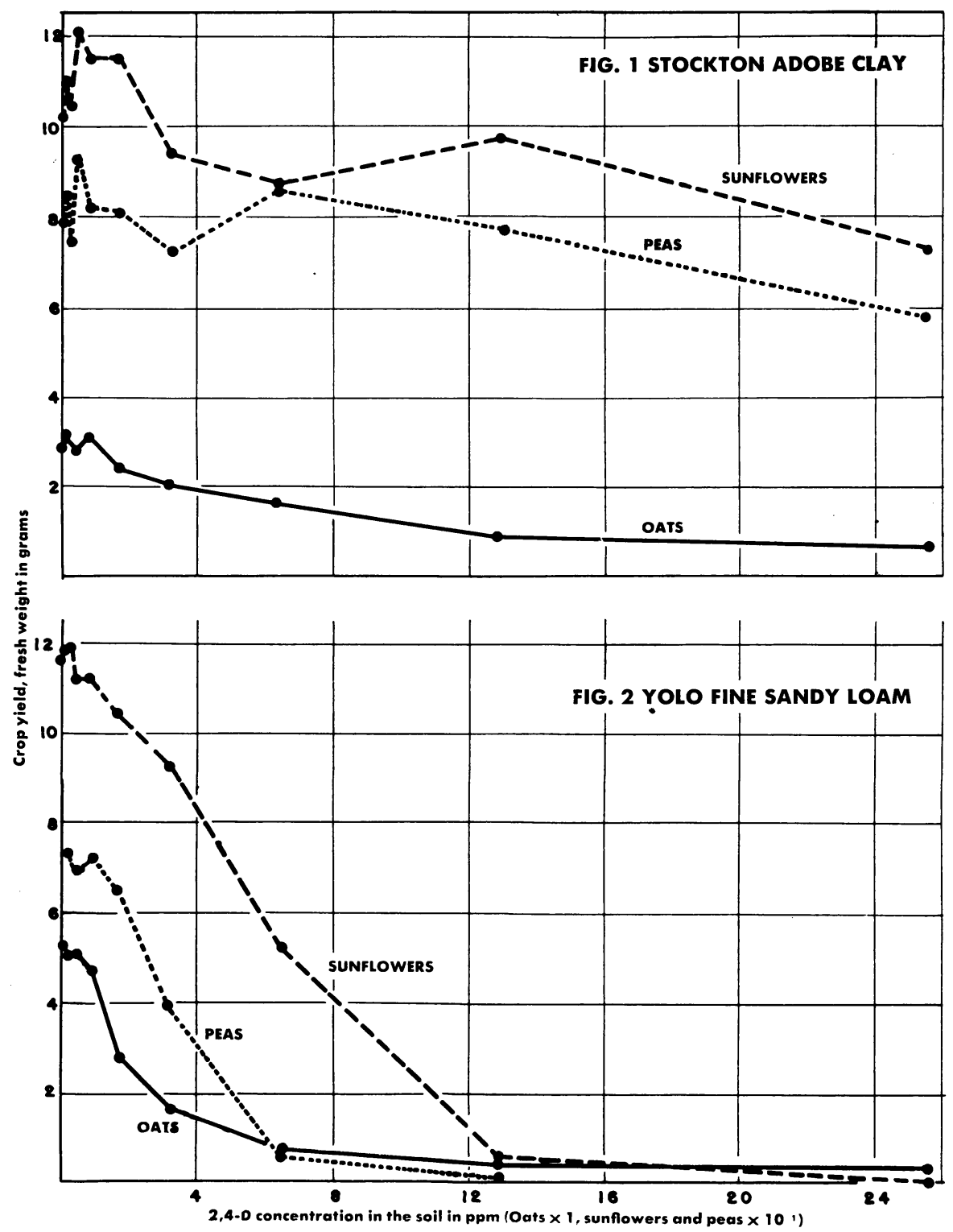

Figs. 1 and 2. Toxicity of 2,4-D to indicator plants in 8 California soils. 


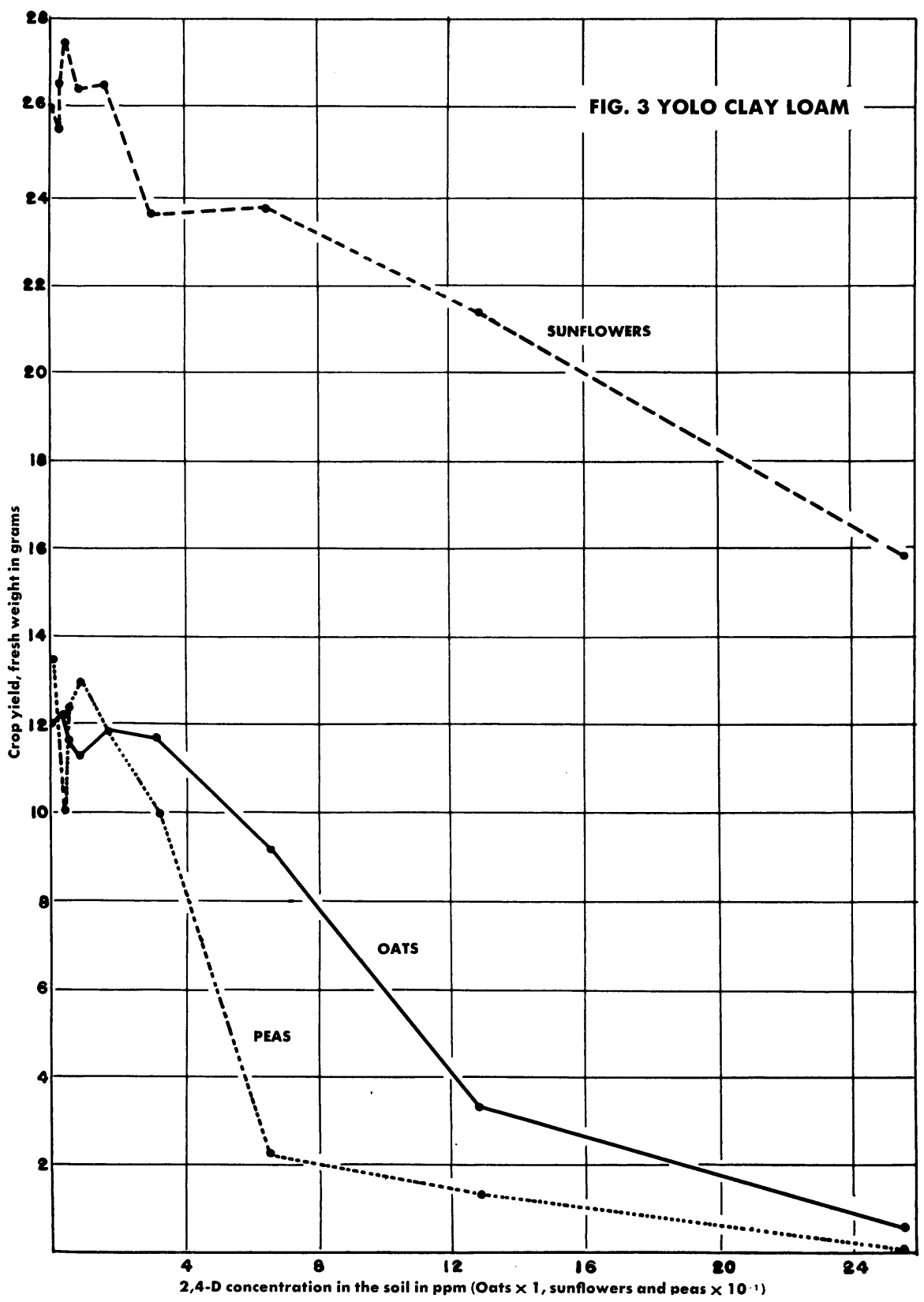

Fig. 3. Toxicity of 2,4-D to indicator plants in 8 California soils. 

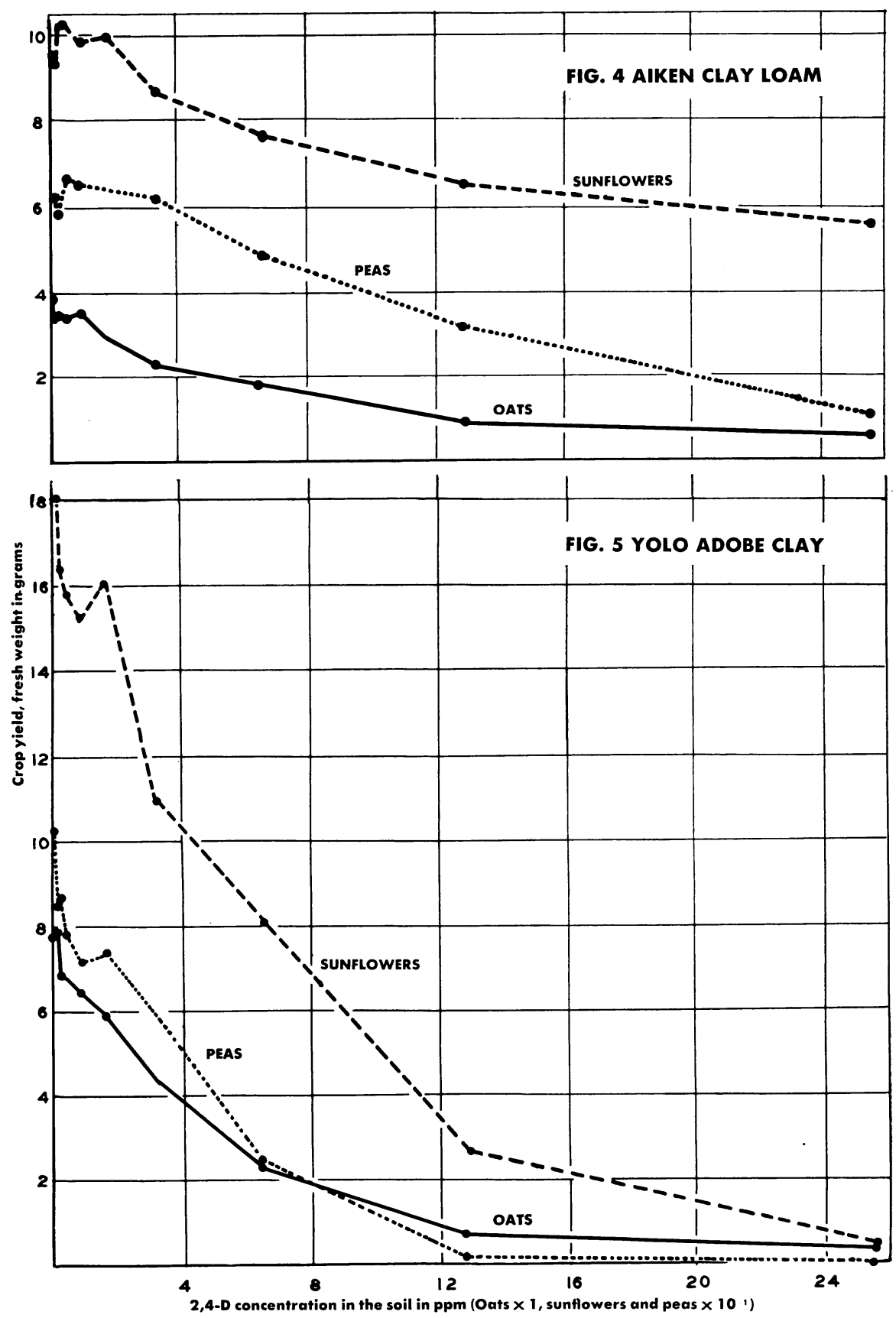

Figs. 4 and 5. Toxicity of 2,4-D to indicator plants in 8 California soils. 
chlorate, thiocyanate, ammate, and phenols, but only in soils where larger amounts of chemical have been involved. Hanks (1946), Taylor (1947), and Kries (1947) all noted stimulation in their studies with 2,4-D.

The consistent differences in toxicity of 2,4-D between oats and the two broad-leafed crops indicate the natural range of biological tolerance to toxic chemicals found wherever plants of widely differing character are tested against a single toxic substance. These differences are the basis for the selec-

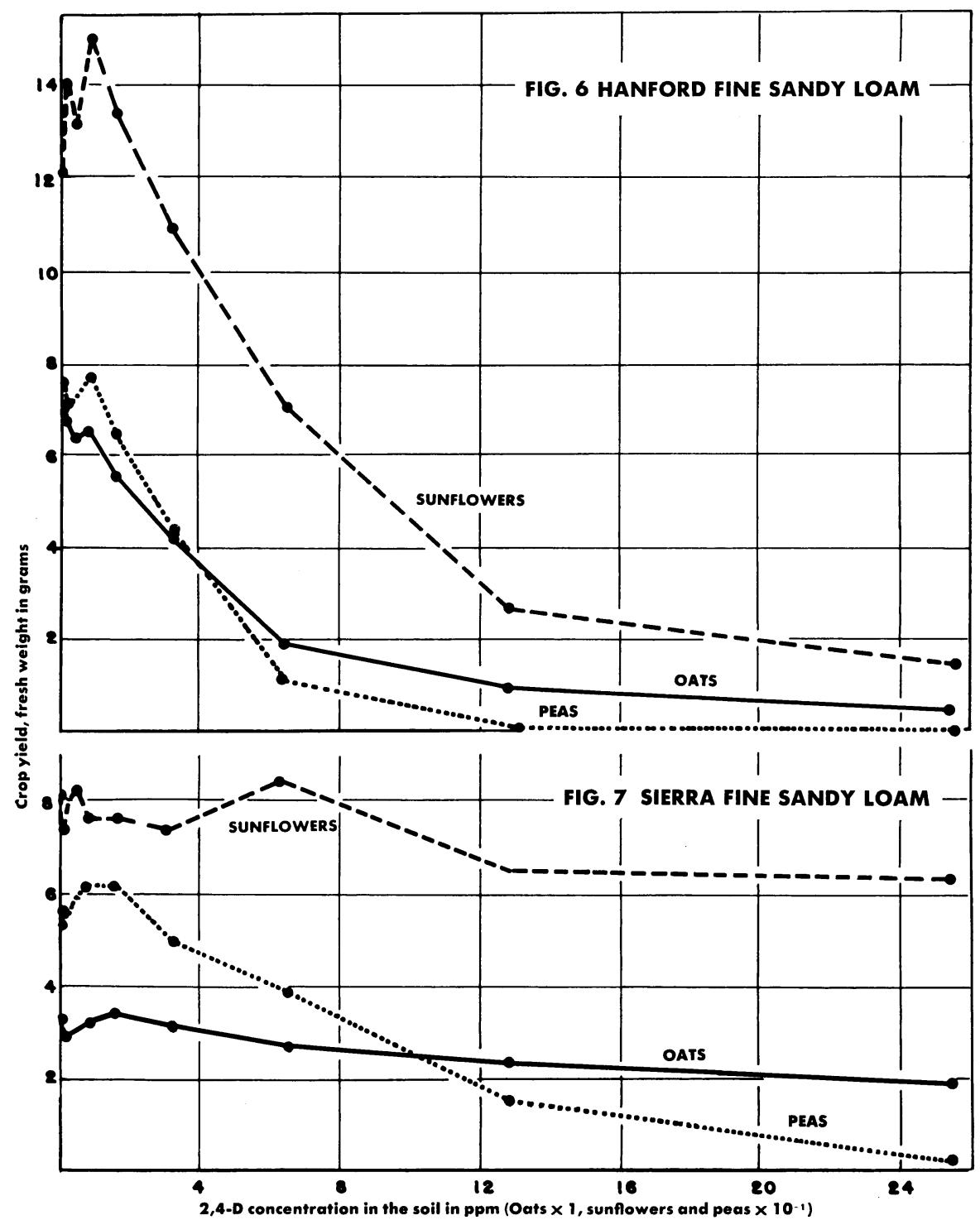

Figs. 6 and 7. Toxicity of 2,4-D to indicator plants in 8 California soils. 
tive action of 2,4-D and other chemicals on weeds in cereals when treated through the soil (Slade, Templeman and Sexton, 1945).

Percolation. Results of percolation tests illustrated by figures 9 and 10 prove that 2,4-D is retained in soils, behaving about like borax in that respect.

Inspection of the graphs on oats shows most of the chemical retained in the top four fractions in Hanford sandy loam, in the top six in Yolo clay loam, in the top six in Stockton adobe clay with some in the seventh and eighth fractions, in the top eight fractions in Fresno loam and in the top nine in Yolo fine sandy loam. As the concentration was increased the chemical tended to occupy more soil, this tendency being stronger in Hanford, Fresno, and Stockton soils than in Yolo. Retention of 2,4-D does not follow any fixed pattern of behavior as does arsenic but varies in such a way that neither textural grade nor parent material gives any clear clue to the factors involved. The retention shown indicates that 2,4-D residues in soils will tend to remain concentrated in surface layers and will not leach as readily as chemicals such as chlorate or nitrate. Results of retention indicated by peas are fairly comparable with those where oats were used, particularly since much lower dos-

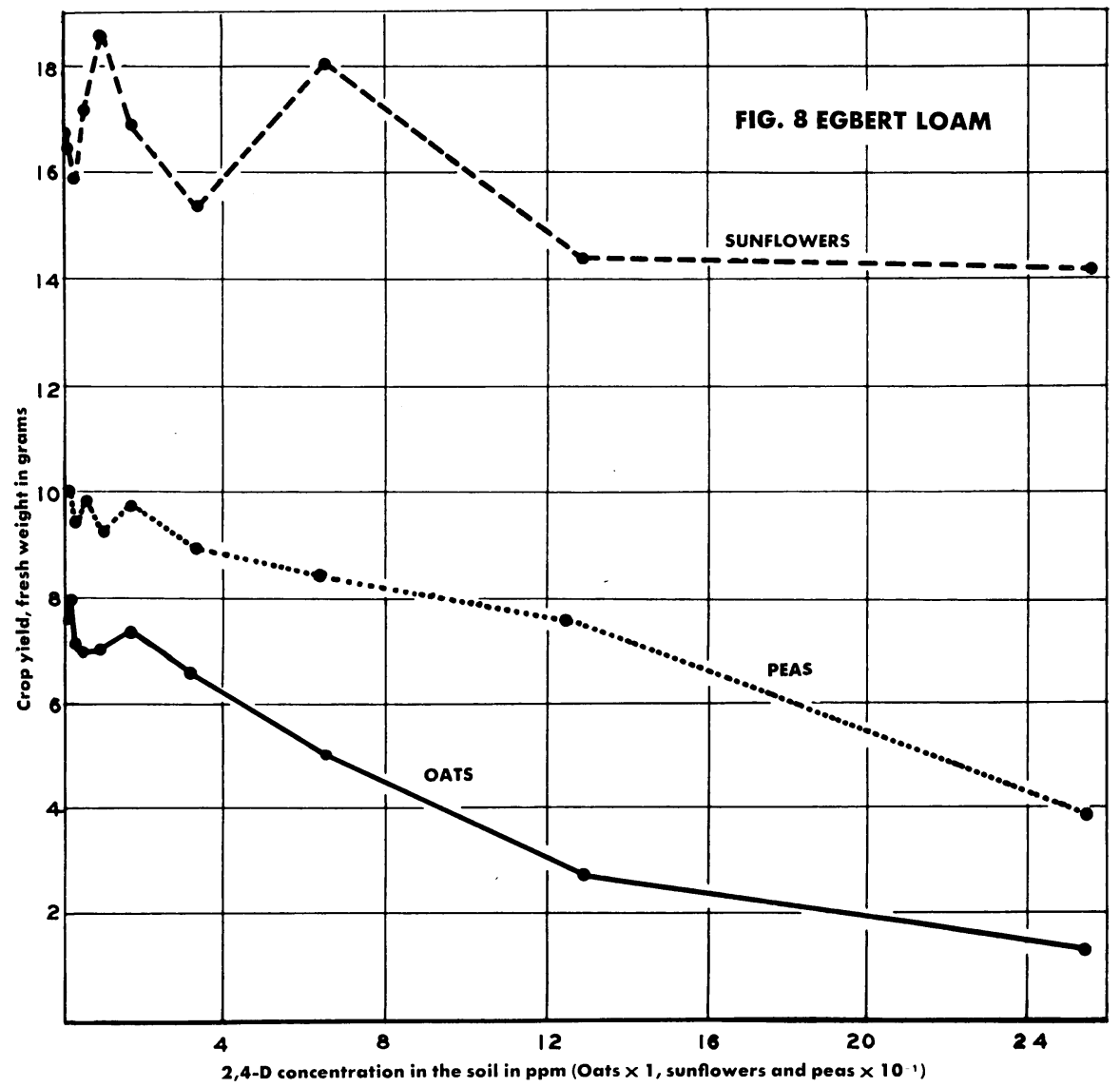

Fig. 8. Toxicity of 2,4-D to indicator plants in 8 California soils. 

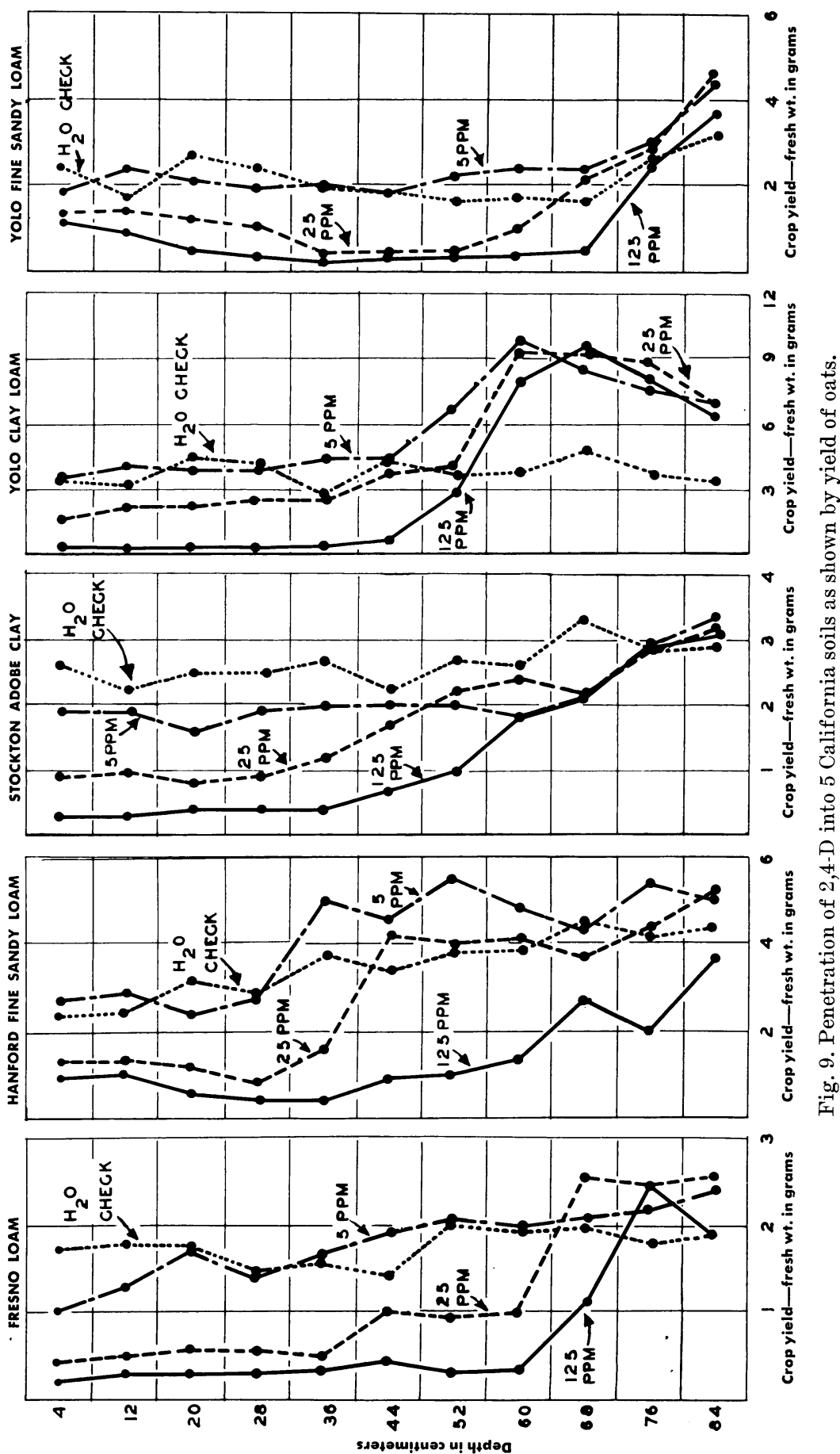

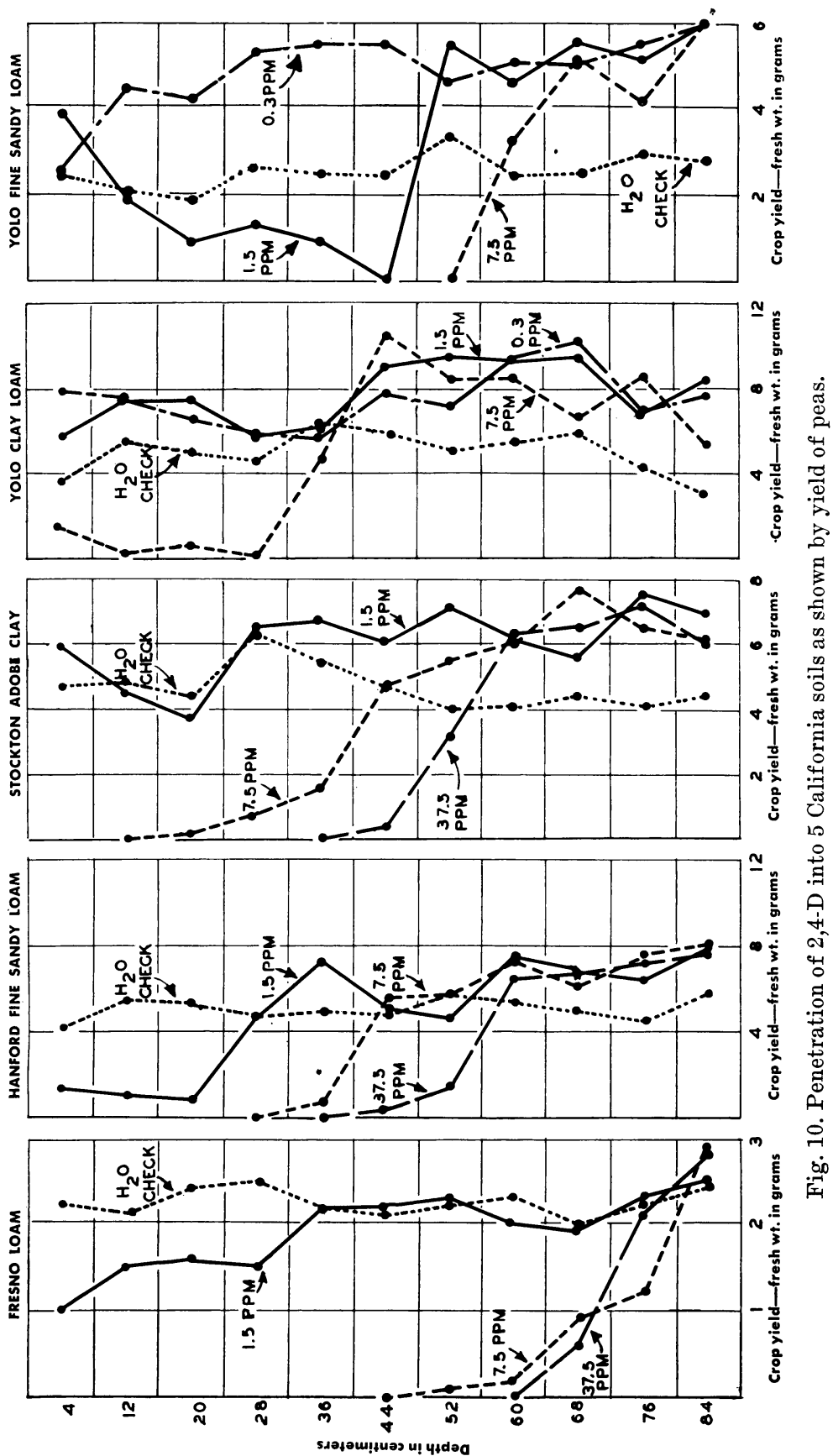
ages caused injury. The initial concentrations were $0.3,1.5$, and 7.5 p.p.m. and the curves for Yolo fine sandy loam illustrate these. Because the 0.3 p.p.m. showed no toxicity the remaining tests were run using 37.5 p.p.m. and leaving off 0.3 p.p.m

Leaching. Using 125 p.p.m. as the initial moistening concentration and oats as indicator plants, leaching tests were run in Stockton adobe clay, Yolo fine sandy loam, and Yolo clay loam. Results are illustrated in figure 11. In Stockton adobe clay the chemical was retained from the initial moistening solution in the top eight fractions. Ten $\mathrm{cm}$ of water lowered the concentration slightly but did not displace the chemical from the top of the column. This application did lower the bottom of the region of concentration into the ninth and tenth fractions. Twenty $\mathrm{cm}$ lowered the concentration appreciably in the top two fractions and probably took a bit of the chemical into the bottom fraction. Forty $\mathrm{cm}$ reduced the concentration even more in the top two fractions and displaced the concentrated layer into the bottom fraction. Eighty $\mathrm{cm}$ lowered the concentration in the third and fourth fractions, 160 lowered it in the nine top fractions, and 320 washed it completely from all but the eleventh fraction.

Leaching displaced the chemical downward somewhat more readily in Yolo fine sandy loam, but in Yolo clay loam the original percolation left the chemical more firmly tied in the soil, leaching was a bit less effective, and even 320 $\mathrm{cm}$ left appreciable concentrations in the tenth and eleventh fractions.

If the curves of figures 9 and 10 are carefully examined it will be found that in several cases crop yields are greater on soils moistened with solutions that originally contained 2,4-D than they are on soils moistened with water. This is evidence again that very low concentrations of 2,4-D are stimulating. This aspect of the use of growth regulators should be thoroughly studied; it indicates a possible use of these materials as a supplement to fertilizer application.

\section{DISCUSSION}

Results of the experiments reported here, plus observations in the field, have led us to the following conclusions :

1. Under California conditions residual toxicity of 2,4-D following spray application is sufficient to cause injury to subsequent crops, the extent of injury depending on temperature, moisture, and soil reaction.

2. In semiarid western states, spraying 2,4-D on foliage gives better and safer weed control than application direct to the soil.

3. Where winter rainfall does not exceed 10 inches, 2,4-D might be used as a permanent soil sterilant, but in general other chemicals are preferable.

Results in the field have proved that 2,4-D will not decompose in soils of the semiarid western states as readily as it does in regions of summer rains. This was predicted from the first preliminary runs in preparation for the studies reported here (Crafts, 1946). Two years' field experience (Harvey and Crafts, 1945) has confirmed the prediction and the results reported here explain the reasons.

Apparently 2,4-D remains active in soils after its application for a period of time depending largely upon temperature and moisture. In practically all cases of injury in the field the soils have been dry while they were warm. 
Moistening by rainfall during the cold winter period did not result in sufficient decomposition to render the soil free of toxicity. Many losses have occurred from spring planting of vegetable varieties on soils sprayed coincidental with weed control during the previous fall.

In the experiments reported here, toxicity was sufficient to reduce growth during the initial cropping period in most soils. By the second crop little toxicity remained. By the third crop, stimulation was evident in many instances. These soils were kept moist during crop growth, and were warm because the greenhouse was heated.

In addition to temperature and moisture, soil reaction evidently affects the residual toxicity of 2,4-D, breakdown being slower in neutral and alkaline soils than in acid ones. Furthermore, an alkaline reaction brings about ionization of 2,4-D producing anions of the active particle. These anions, because of their negative charge, would not readily enter bacteria or fungi, and would not tend to adsorb on soil colloids. They could be taken up by plant roots, which are highly specialized for absorbing ions, and their presence in the plant would result in injury (Crafts, 1948b). These facts help to explain the slow breakdown and high residual toxicity of 2,4-D observed so often in the field.

Although the small number and wide variety of soils tested by percolation
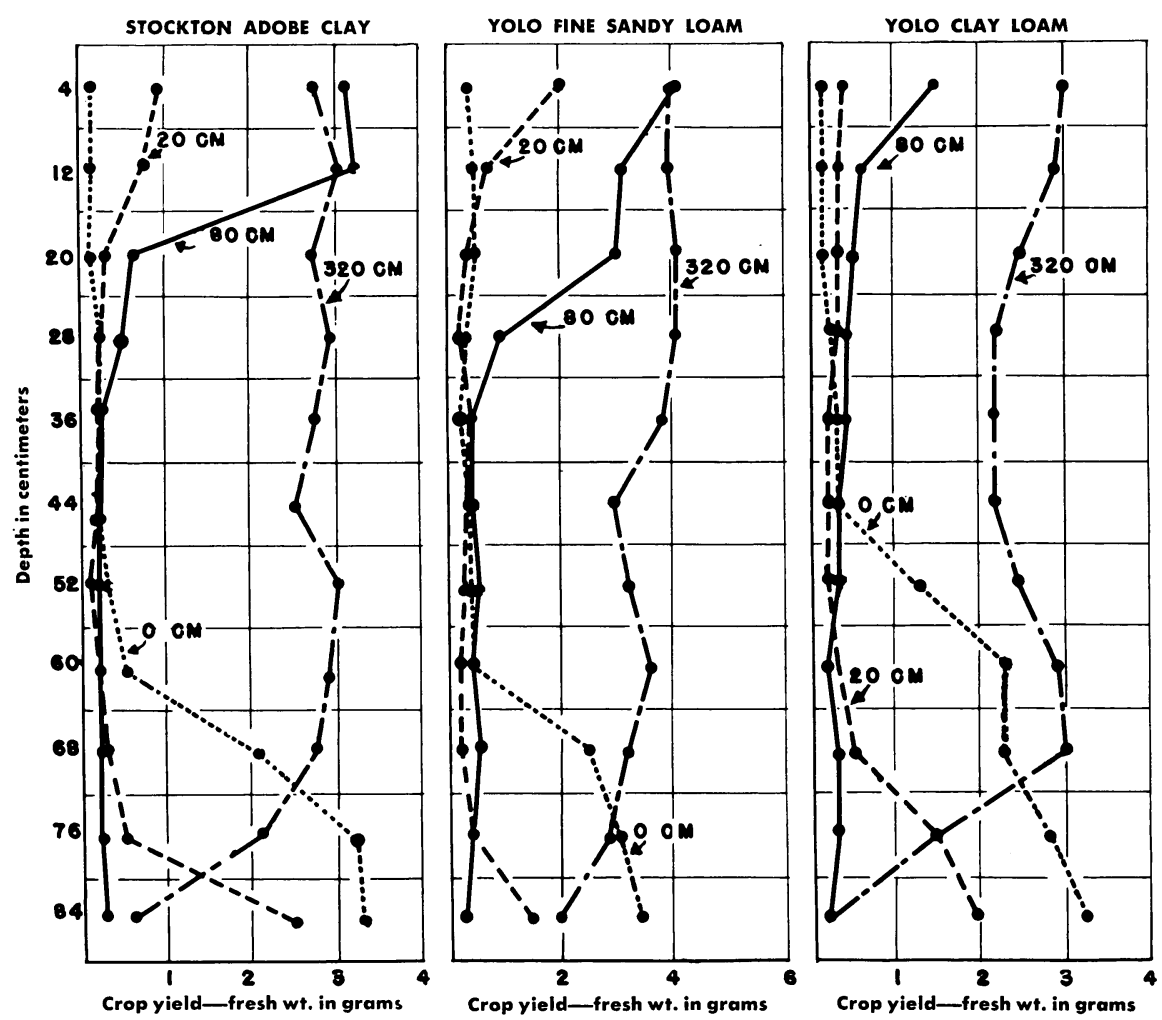

Fig. 11. Leaching of 2,4-D from 3 California soils as shown by yield of peas. 
led to no obvious relations between 2,4-D retention and soil properties, the experiments proved that this chemical does not move freely with the moistening water but remains behind, held to the soil by binding forces of moderate strength. Weaver (1947) showed that both cation and anion exchangers hold 2,4-D. In soils this chemical is probably held by the clay colloids in such a form that at least a part of it is available to plants.

Though leaching resulted in some displacement of the chemical downward, the complete freeing of the soil of 2,4-D was not accomplished in two soil types with 320 surface centimeters. These results indicate that ridding the soil of 2,4-D under conditions where chemical breakdown does not occur may prove to be a real problem.

That the leaching and decomposition normally occurring during the winter are not sufficient under central California conditions is indicated by many field experiences. For example, one grower sprayed morning glory patches in a field in the fall, plowed 12 inches deep in the spring, prepared the seed bed, and planted onions. The crop failed to come up in the sprayed areas. Apparently the 2,4-D had been leached to a depth of about 12 inches, and was turned up to the surface with the deep plowing. Similar cases have been observed where shallow seedbed preparation was used. Seeds came up and made healthy seedlings, only to fail when the roots grew down into the zone containing the chemical.

Where 2,4-D is applied during spring or early summer, probably light irrigation during midsummer to provide a warm, moist condition will prove the most practical means of eliminating it by decomposition. Where application is made during the autumn and leaching by winter rains occurs, further leaching in the spring seems to be indicated.

The above discussion shows beyond doubt that 2,4-D residues constitute a real problem in California soils and that soil properties and precipitation determine the location and toxicity of the chemical. Leaching and decomposition are both concerned in the disappearance of the chemical from a given soil horizon, and temperature as well as moisture must be suitable if the latter is to be effective. Where decomposition cannot be depended upon, leaching is indicated when it is necessary to crop the treated land. When leaching is practiced, sufficient water must be used to carry the chemical beyond the zone of root growth of the crop or to dilute and spread it sufficiently to overcome the toxicity.

Concerning the use of 2,4-D as a selective herbicide through soil application, the experiments described above indicate the range of tolerance of one cereal crop and show the wide selectivity that may exist. They do provide a clue to the inadequacy of the method under the semiarid conditions of California, but field tests (Harvey and Crafts, 1945) were required to prove its weakness. Such tests showed that when only light rainfall occurred following application of 2,4-D to the soil, a shallow concentrated layer of the chemical surrounding the roots of the developing crop seedlings resulted in serious crippling of the plants despite the wide range of selectivity between crop and weeds. Protracted heavy rains, on the other hand, may leach the chemical so deep into the soil that weed seedlings germinating later in the season will survive and compete successfully with the crop. 
Many field tests have proved the very practical nature of the spray method of applying 2,4-D, by which the foliage of the weeds is contacted directly. An estimated quarter million acres of cereal crops in California were sprayed in the spring of 1947. Weeds (principally wild mustard and radish) from the small seedling stages up to the blossoming condition were quickly killed, whereas the only injury to crops occurred either when spraying was done on very young seedling grain during the cold winter season or when grain coming out of the boot was treated. Early treatment resulted in crippling some oat and barley plants due to abnormal growth. Late treatment caused twisting of heads and failure to fill in a few instances.

These experiments with 2,4-D in soils show that this chemical can sterilize the soil against plant growth. However, 2,4-D leaches too readily and decomposes in warm, moist soils too rapidly to be of general use as a permanent soil sterilant. In regions where rainfall occurs only during the winter and does not exceed 10 inches, 2,4-D might prove useful for permanent soil sterilization, so long as the price remains in the neighborhood of 50 cents per pound. In most localities, however, chlorate, borax, or arsenic trioxide, properly applied, can better fulfill practically all requirements for permanent sterilization of soils.

A much more fertile field for the large-scale employment of 2,4-D would seem to be that of pre-emergence treatment in corn and sugar cane, and spraying for pasture and range improvement. When the critical aspects of preemergence treatment are appreciated, this method will undoubtedly be widely used (Crafts, 1948a). The low-volume method of applying 2,4-D which has received so much attention and has given such promising results seems applicable to programs of brush control (Barrons and Coulter, 1948) and range improvement exceeding anything that has ever been planned in the past. In such programs the residues of 2,4-D, far from inhibiting range crops, may actually stimulate grasses as they have seedlings and crop plants growing in soils where decomposition has eliminated toxicity (tables 1-4, 3rd and 4th runs).

\section{ACKNOWLEDGMENT}

The writer is indebted to Harold R. Drever, Senior Laboratory Technician, Division of Botany, Davis, for his help in growing the greenhouse plants used in these studies. 


\section{LITERATURE CITED}

Barrons, K. C., and L. L. Coulter.

1948. Year-round stump treatment for woody plant control. Down to Earth 4(2):4.

CRAFTs, A. S.

1935. The toxicity of sodium arsenite and sodium chlorate in four California soils. Hilgardia $9: 461-498$.

Crafts, A. S.

1945. Toxicity of certain herbicides in soils. Hilgardia 16:459-483.

Crafts, A. S.

1946. The 2,4-D weed killers : a warning. California Dept. Agr. Bul. 35:34-36.

CRAFTs, A. S.

1948a. Results of soil treatment vs. contact sprays in corn and cane weed control. Agr. Chem. 3(5):25-27, 81, 83, 85 .

Crafts, A. S.

$1948 b$. A theory of herbicidal action. Science 108(2795):85-86.

Crafts, A. S., and R. N. RAYNoR.

1936. The herbicidal properties of boron compounds. Hilgardia 10:343-374.

CRAFTs, A. S., and R. S. Rosenfels.

1939. Toxicity studies with arsenic in eighty California soils. Hilgardia 12:177-200.

De Rose, H. R.

1946. Persistence of some plant growth-regulators when applied to the soil in herbicidal treatments. Bot. Gaz. 107:583-589.

HANKS, R. W.

1946. Removal of 2,4-dichlorophenoxyacetic acid and its calcium salt from six different soils by leaching. Bot. Gaz. 108:186-191.

Harvey, W. A., and A. S. Craf'Ts.

1945. Results of tests on 2,4-D weed killers in California. Unpublished.

KRIES, OLIVE H.

1947. Persistence of 2,4-dichlorophenoxyacetic acid in soil in relation to content of water, organic matter, and lime. Bot. Gaz. 108:510-525.

Nutman, P. S., H. G. Thornton, and J. H. Quastel.

1945. Inhibition of plant growth by 2,4-dichlorophenoxyacetic acid and other plant growth substances. Nature 155:498-500.

ROSENFELS, R. S., and A. S. Crafts.

1939. Arsenic fixation in relation to the sterilization of soils with sodium arsenite. Hilgardia 12:204-229.

Slade, R. E., W. G. Templeman, and W. A. Sexton.

1945. Plant-growth substances as selective weed killers. Nature 155:497-498.

TAYLOR, D. L.

1947. Growth of field erops in soil treated with chemical growth-regulators. Bot. Gaz. $108: 432-445$.

WEAVER, R. J.

1947. Reaction of certain plant growth-regulators with ion exchangers. Bot. Gaz. 109: $72-84$. 
The journal Hilgardia is published at irregular intervals, in volumes of about 600 pages. The number of issues per volume varies.

Subscriptions are not sold. The periodical is sent as published only to libraries or to institutions in foreign countries having publications to offer in exchange.

You may obtain a single copy of any issue free, as long as the supply lasts; please request by volume and issue number from:

\section{Publications Office \\ College of Agriculture \\ Berkeley 4, California}

The limit to nonresidents of California is 10 separate issues on a single order. A list of the issues still available will be sent on request. 
